\title{
Corrigendum to "Cell Cycle Genes Are Potential Diagnostic and Prognostic Biomarkers in Hepatocellular Carcinoma"
}

\author{
Xu Liping $\mathbb{D}^{1},{ }^{1}$ Li Jia, ${ }^{2}$ Chen $Q i,{ }^{1}$ Yang Lian, ${ }^{1}$ Li Dongen, ${ }^{1}$ and Jiang Jianshuai $\mathbb{D}^{1}$ \\ ${ }^{1}$ Department of Hepatobiliary Pancreatic Surgery, Ningbo First Hospital, Ningbo, Zhejiang Province, China \\ ${ }^{2}$ Department of Breast and Thyroid, Shanghai Tenth People's Hospital, Tongji University School of Medicine, Shanghai, China \\ Correspondence should be addressed to Jiang Jianshuai; jiainna000@gmail.com
}

Received 18 November 2020; Accepted 18 November 2020; Published 28 November 2020

Copyright (c) $2020 \mathrm{Xu}$ Liping et al. This is an open access article distributed under the Creative Commons Attribution License, which permits unrestricted use, distribution, and reproduction in any medium, provided the original work is properly cited.

In the article titled "Cell Cycle Genes Are Potential Diagnostic and Prognostic Biomarkers in Hepatocellular Carcinoma" [1], information was omitted from Acknowledgments in error. Acknowledgments is shown below.

\section{Acknowledgments}

This work was supported by grants from the National Key R\&D Program of China (2017YFC0114102).

\section{References}

[1] X. Liping, L. Jia, C. Qi, Y. Liang, L. Dongen, and J. Jianshuai, "Cell cycle genes are potential diagnostic and prognostic biomarkers in hepatocellular carcinoma," BioMed Research International, vol. 2020, Article ID 6206157, 12 pages, 2020. 